\title{
Effects of fish age versus size on the development of whirling disease in rainbow trout
}

\author{
Eileen K. N. Ryce ${ }^{1, *}$, Alexander V. Zale ${ }^{1}$, Elizabeth MacConnell ${ }^{2}$, Mark Nelson ${ }^{1}$ \\ ${ }^{1}$ Montana Cooperative Fishery Research Unit, US Geological Survey, Department of Ecology, Montana State University, \\ Bozeman, Montana 59717, USA
}

${ }^{2}$ US Fish and Wildlife Service, Bozeman Fish Health Laboratory, 920 Technology Boulevard, Bozeman, Montana 59715, USA

\begin{abstract}
We examined the effects of both fish age and size on the development of resistance to whirling disease in Erwin strain rainbow trout. Previously, we demonstrated that juvenile rainbow trout became resistant to development of the disease when first exposed to triactinomyxons of the parasite Myxobolus cerebralis at about 9 wk post-hatch when raised at $12^{\circ} \mathrm{C}$, but ages and sizes of fish used in that experiment were confounded (Ryce EKN, Zale AV, MacConnell E [2004] Dis Aquat Org 59:225-233). In this study, rainbow trout of the same age and different sizes, and the same size and different ages, were exposed to the parasite to distinguish the influences of age and size. Fish were reared at 3 different water temperatures prior to exposure to produce groups with different growth rates and were exposed to the parasite at 7 or 9 wk post-hatch. Disease severity was affected by both age and size at first exposure, but the effects were not independent. An increase in fork length from 36 to $40 \mathrm{~mm}$ among fish exposed at $7 \mathrm{wk}$ post-hatch did not confer increased resistance, but the same increase in size at $9 \mathrm{wk}$ post-hatch did. Similarly, an increase in age from 7 to $9 \mathrm{wk}$ posthatch among fish exposed at $36 \mathrm{~mm}$ fork length did not confer increased resistance, but the same increase in age at $40 \mathrm{~mm}$ did. Rainbow trout must be both $9 \mathrm{wk}$ post-hatch or older and at least $40 \mathrm{~mm}$ in fork length at time of exposure to exhibit enhanced resistance to whirling disease. Resistance to disease was not associated with the level of skeletal ossification.
\end{abstract}

KEY WORDS: Myxobolus cerebralis · Whirling disease $\cdot$ Resistance $\cdot$ Age $\cdot$ Size $\cdot$ Rainbow trout

\section{INTRODUCTION}

The development and severity of whirling disease pathology in salmonids has long been known to be dependent generally on the age or size of fish when first exposed to Myxobolus cerebralis triactinomyxons (O'Grodnick 1979, Markiw 1991, 1992, Thompson et al. 1999). Fish older than about 4 to 8 mo or longer than about 5 to $13 \mathrm{~cm}$ were believed to be disease resistant (Hoffman 1961, Halliday 1976, Hoffman 1976, Wolf 1986, Lom 1987, Schaperclaus 1991, Garden 1992). We recently demonstrated that rainbow trout become resistant to the development of whirling disease at about 9 wk post-hatch or older when raised at $12^{\circ} \mathrm{C}$ (Ryce et al. 2004). However, ages and sizes of fish used in that experiment were confounded and we could not determine whether the development of resistance was associated with increasing age or size of the fish at time of exposure, or perhaps a co-variate of one or both, such as skeletal ossification. The trophozoites of $M$. cerebralis digest cartilage and destroy the structural framework needed for healthy bone formation (El-Matbouli et al. 1992), leaving fish permanently disfigured. The abundant cartilage in the skeleton of young trout is therefore thought to render them highly susceptible to the effects of the disease (Halliday 1973, Schaperclaus 1991, El-Matbouli et al. 1992, Garden 1992). In the present investigation, our objective was to determine whether age or size governs development of resistance to the disease. We also compared the level of skeletal ossification in rainbow trout at time of exposure to the subsequent severity of whirling disease. 


\section{MATERIALS AND METHODS}

Experimental procedures. Erwin strain rainbow trout were hatched from eggs supplied by the Ennis National Fish Hatchery, United States Fish and Wildlife Service, Ennis, MT, and were maintained at the Bozeman Fish Technology Center, Bozeman, MT, until exposure. After hatch, the fish were reared at one of 3 water temperatures $\left(9.3,12.0\right.$ or $\left.15.4^{\circ} \mathrm{C}\right)$ to produce 3 groups of fish with different growth rates and therefore different accumulated degree days of development and sizes at the same ages. The fish were exposed to Myxobolus cerebralis triactinomyxons at 7 or 9 wk post-hatch, yielding exposures at each of 6 age-size combinations (see Table 1) including 3 sizes (and corresponding degree days of development) at each of the 2 ages $(28,36$ and $40 \mathrm{~mm}$ fork length at 7 wk post-hatch and 36, 40 and $46 \mathrm{~mm}$ at $9 \mathrm{wk}$ posthatch) and 2 ages ( 7 and 9 wk post-hatch) at each of 2 sizes (36 and $40 \mathrm{~mm}$ ). We selected these ages and sizes to encompass the approximate thresholds at which enhanced resistance commences (Ryce et al. 2004). Each exposure included negative controls (3 replicates) and exposures to 1000 triactinomyxons per fish (3 replicates). Each replicate consisted of 40 fish. M. cerebralis triactinomyxons were produced in the laboratory from cultures of infected Tubifex tubifex (Hedrick et al. 1999b). Exposures were conducted at the Wild Trout Research Laboratory, Montana State University, Bozeman, MT. Each replicate was exposed to $M$. cerebralis triactinomyxons or a sham exposure in aerated 51 exposure chambers for 2 h (Hedrick et al. 1999a). Following exposure, replicates were maintained separately at $13^{\circ} \mathrm{C}$ in $38 \mathrm{l}$ glass aquaria supplied with filtered and oxygenated water by a recirculating process system at the Wild Trout Research Laboratory. The fish were fed a commercial trout diet at 2 to $3 \%$ body weight $\mathrm{d}^{-1}$. Mortalities were counted and removed daily.
Whirling disease severity was characterized using cumulative mortality, swimming performance, clinical signs of disease, microscopic pathology categories and myxospore burdens at 20 wk post-exposure. Multiple indicators were used to provide a comprehensive evaluation of disease severity. Clinical signs (i.e. any combination of blacktail, skeletal deformities or whirling behavior) were recorded for all surviving fish in each replicate. Swimming performance, microscopic pathology and myxospore burdens of 9 randomly selected individuals from each replicate (i.e. 27 fish per treatment) were assessed. Swimming performance was measured as the length of time a fish could maintain its position in a stamina tunnel (Wedemeyer et al. 1990) at a constant, pre-selected water velocity $\left(35 \mathrm{~cm} \mathrm{~s}^{-1}\right)$. Swimming performance tests are a convenient means to assess the physical condition of fish (Wedemeyer et al. 1990) as well a good indicator of stress (Webb \& Brett 1973). Impairment of swimming performance correlates to reduced survival (Thomas et al. 1964). After testing, fish were euthanized.

The heads of the euthanized fish were removed, cut in half along the midsagittal plane, preserved in Davidson's fixative and prepared for microscopic examination using standard histological techniques. One head half and the tail from each fish were prepared for histology. Microscopic pathology was categorized according to the MacConnell-Baldwin Scale (Hedrick et al. 1999b), whereby cartilaginous tissue was examined for the presence of the parasite and associated lesions. The abundance of parasites, cartilage damage, inflammation, extent of lesions, involvement of other tissues and bone distortion were evaluated and categorized into one of 6 qualitative categories: no infection, minimal, mild, moderate, high or severe. In total, 2 head sections and 2 tail sections were evaluated histologically for each fish collected.

Table 1. Myxobolus cerebralis infecting Oncorhynchus mykiss. Age at exposure, mean length at exposure, rearing temperature and degree days of development prior to exposure. Results of Bonferroni's multiple comparison tests for mean time to fatigue, mean percentage of incidence of clinical signs, and mean myxospore burden of fish exposed to 1000 triactinomyxons per fish are shown together with mean percentage of skeletal cartilage at exposure. Different letters denote significant differences in response $(\mathrm{p}<0.05)$

\begin{tabular}{|c|c|c|c|c|c|c|c|c|c|c|c|}
\hline \multirow{3}{*}{$\begin{array}{l}\text { Age } \\
\text { (wk post- } \\
\text { hatch) } \\
7\end{array}$} & \multirow{3}{*}{$\begin{array}{c}\text { Fork length } \\
(\mathrm{mm} \pm \mathrm{SE})\end{array}$} & \multirow{3}{*}{$\begin{array}{c}\begin{array}{c}\text { Rearing } \\
\text { temperature } \\
\left({ }^{\circ} \mathrm{C}\right)\end{array} \\
9.3\end{array}$} & \multirow{3}{*}{$\begin{array}{c}\text { Degree } \\
\text { days } \\
456\end{array}$} & \multicolumn{7}{|c|}{$\longrightarrow$ Multiple comparisons } & \multirow{2}{*}{$\begin{array}{c}\text { Cartilage } \\
(\% \pm \mathrm{SE})\end{array}$} \\
\hline & & & & \multicolumn{2}{|c|}{$\begin{array}{l}\text { Time to } \\
\text { fatigue }\end{array}$} & \multicolumn{2}{|c|}{$\begin{array}{l}\text { Clinical } \\
\text { signs }\end{array}$} & \multicolumn{3}{|c|}{$\begin{array}{l}\text { Myxospore } \\
\text { burden }\end{array}$} & \\
\hline & & & & $\mathrm{z}$ & & $\mathrm{z}$ & & $\mathrm{z}$ & $\mathrm{y}$ & & $81.03 \pm 3.46$ \\
\hline 7 & $36 \pm 0.83$ & 12.0 & 588 & $\mathrm{z}$ & y & $\mathrm{z}$ & y & & $\mathrm{y}$ & $\mathrm{x}$ & $41.70 \pm 2.72$ \\
\hline 7 & $40 \pm 0.53$ & 15.4 & 755 & $\mathrm{z}$ & $\mathrm{y}$ & $\mathrm{z}$ & $\mathrm{y}$ & & $\mathrm{y}$ & $\mathrm{x}$ & $47.51 \pm 5.77$ \\
\hline 9 & $36 \pm 0.47$ & 9.3 & 586 & $\mathrm{z}$ & $\mathrm{y}$ & & $\mathrm{y}$ & $\mathrm{z}$ & & & $49.29 \pm 3.01$ \\
\hline 9 & $40 \pm 0.64$ & 12.0 & 756 & & $\mathrm{y}$ & & $\mathrm{x}$ & $\mathrm{z}$ & & & $41.56 \pm 2.81$ \\
\hline 9 & $46 \pm 0.69$ & 15.4 & 970 & & $\mathrm{y}$ & & $\mathrm{x}$ & & & $\mathrm{x}$ & $44.46 \pm 3.94$ \\
\hline
\end{tabular}


The remaining halves of the heads were used to obtain myxospore counts using the standard planktoncentrifuge extraction method (O'Grodnick 1975). After extraction, myxospores were resuspended in a known volume of deionized water and $1 \mathrm{ml}$ aliquots were placed on both sides of a standard $1 \mathrm{ml}$ hemocytometer counting chamber. Total spores per original head were estimated by extrapolation. Three estimates were made for each head; the mean of the 3 was used in analyses.

Bias was reduced throughout the experiment. Fish were randomly assigned to replicates and replicates were assigned to tanks randomly. Mortalities and clinical signs were recorded blindly for each replicate. Sampled fish were selected randomly. Histology slides and myxospore samples were examined blindly and in random order. The exposure designation of each sample was not determined until all samples had been examined and recorded.

The percentages of cartilage and ossified bone at time of exposure were estimated in 10 randomly selected fish from each of the 6 age-size groups. These fish were not used in the experiment. They were euthanized at the time of exposure, fixed in $10 \%$ buffered formalin and preserved in $75 \%$ ethanol. Cartilage and bone were differentially stained using alcian blue and alizarin red S (Fritzsche \& Johnson 1980, Webb \& Byrd 1994, Song \& Parenti 1995, Ryce 2003). A digital image of each fish (Fig. 1) was processed using image analysis software (Image-Pro Express 4.0). Regions of the skeleton were designated as blue (cartilage) or red (ossified bone) and the area of each color was determined to calculate the ratio of cartilage to bone in the entire skeleton.

Statistical analyses. The experiment was designed and analyzed as a 3-way factorial. The 3 factors, or treatments, were age of fish at exposure ( 7 or $9 \mathrm{wk}$ post-hatch), mean size at exposure (28, 36,40 or $46 \mathrm{~mm}$ fork length) and parasite dose (0 or 1000 triactinomyxons per fish). The number of mortalities, percentage of fish with clinical signs, myxospore counts, swimming performance and microscopic pathology were compared among the 12 treatment groups (i.e. 6 age-size combinations and 2 parasite dose levels). All responses were treated parametrically except microscopic pathology. Microscopic pathology categories are ordinal but thresholds across categories (i.e. the differences between categories) cannot be assumed to be equal. Therefore, we used the nonparametric chi-square test of homogeneity (Daniel 1990) to determine whether age or size at expo-sure significantly affected microscopic pathology.

Myxospore counts and swimming performance were analyzed with random factors included in the model for tank and fish, and the fish were treated as the experimental unit. Mortality and clinical signs were analyzed in the same way as myxospore counts and swimming performance, with the exceptions that tanks were the experimental units and no factor for fish was included in the model. A mixed linear model was used that combined both the fixed (age and size of fish at exposure and parasite dose) and random (tank and fish) effects. Type III F-statistics were used (Montgomery 1997). The important assumptions supporting this analysis are that the data are normally distributed and that they are independent with constant variance. Visual inspection of residual plots of data for all responses confirmed that these assumptions were met. The units of measure (fish or tank) were not independent; however, this assumption could be dropped by modeling statistical correlation into the analysis, which assumes constant variance and constant covariance (PROC MIXED, compound symmetry covariance option; Littell et al. 1996). The model used for the analysis was the following:

$$
\begin{aligned}
y_{i j k l m n}= & \mu+\alpha_{i}+\beta_{j}+\tau_{k}+(\alpha \beta)_{i j}+(\alpha \tau)_{i k}+(\beta \tau)_{j k}+(\alpha \beta \tau)_{i j k} \\
& +\gamma_{l(i j k)}+\delta_{m(i j k l)}+\varepsilon_{i j k l m n}
\end{aligned}
$$

where $i=1, \ldots, \mathrm{a} ; j=1, \ldots, \mathrm{b} ; k=1, \ldots, \mathrm{c} ; l=1, \ldots, \mathrm{d} ; m=$ $1, \ldots, \mathrm{e}_{i} n=1, \ldots, \mathrm{f}$, and parameters sybolized by Greek letters are defined in Table 2.

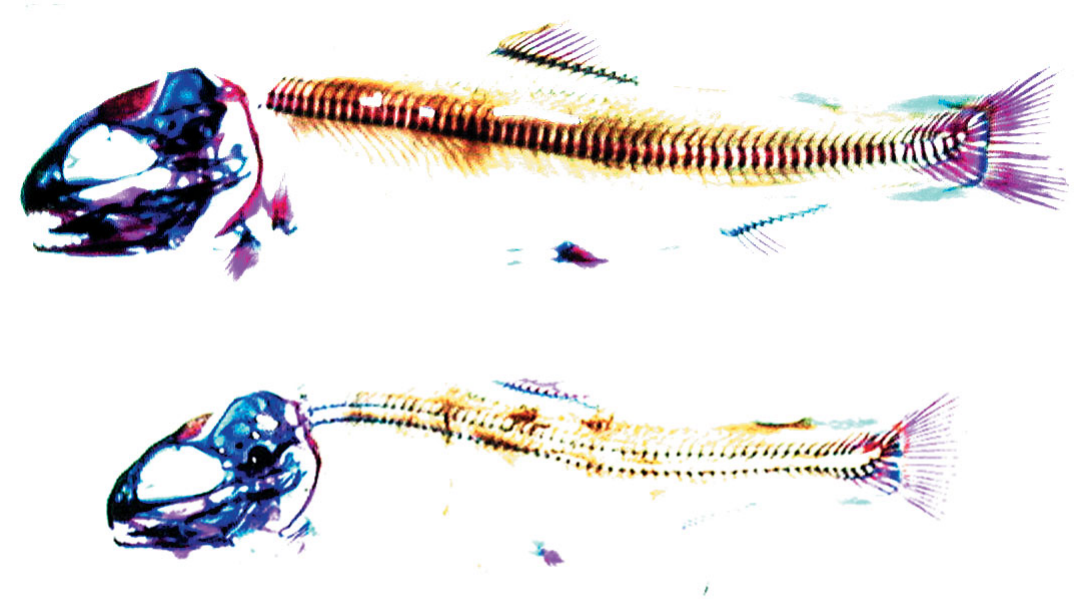

Fig. 1. Oncorhynchus mykiss. Rainbow trout differentially stained using alcian blue and alizarin red S. Cartilage is blue and ossified bone is red. The upper fish was 7 wk post-hatch, reared at $12^{\circ} \mathrm{C}, 35 \mathrm{~mm}$ fork length and its skeleton was $52 \%$ cartilage ( $48 \%$ bone). The lower fish was $7 \mathrm{wk}$ post-hatch, reared at $9.3^{\circ} \mathrm{C}$, $29 \mathrm{~mm}$ fork length and its skeleton was $80 \%$ cartilage ( $20 \%$ bone) 
Table 2. Model parameters

\begin{tabular}{|c|c|}
\hline Parameter & Definition \\
\hline$\mu$ & Overall mean \\
\hline$\alpha_{i}$ & $\begin{array}{l}\text { Effect of the ith level of the fixed factor } \\
\text { A (age of fish at exposure) }\end{array}$ \\
\hline$\beta_{j}$ & $\begin{array}{l}\text { Effect of the } j \text { th level of the fixed factor } \\
\text { B (size of fish at exposure) }\end{array}$ \\
\hline$\tau_{k}$ & $\begin{array}{l}\text { Effect of the } k \text { th level of the fixed factor } \\
\text { C (parasite dose) }\end{array}$ \\
\hline$(\alpha \beta)_{i j}$ & $\begin{array}{l}\text { Interaction effect between the ith level } \\
\text { of factor } \mathrm{A} \text { and the } j \text { th level of factor B }\end{array}$ \\
\hline$(\alpha \tau)_{i k}$ & $\begin{array}{l}\text { Interaction effect between the ith level } \\
\text { of factor A and the } k \text { th level of factor C }\end{array}$ \\
\hline$(\beta \tau)_{j k}$ & $\begin{array}{l}\text { Interaction effect between the } j \text { th level } \\
\text { of factor B and the } k \text { th level of factor C }\end{array}$ \\
\hline$(\alpha \beta \tau)_{i j k}$ & $\begin{array}{l}\text { Interaction effect between the } i \text { th level } \\
\text { of factor A, the } j \text { th level of factor B and } \\
\text { the } k \text { th level of factor C }\end{array}$ \\
\hline$\gamma_{(i j k)}$ & $\begin{array}{l}\text { Effect of the lth level of the random factor } \\
D \text { (tank nested in factors A, B, and C) }\end{array}$ \\
\hline$\delta_{m(i j k l)}$ & $\begin{array}{l}\text { Effect of the } m \text { th level of the random } \\
\text { factor E (fish nested in factors A-D; this } \\
\text { effect is not included in the model when } \\
\text { analyzing the mortality or clinical signs } \\
\text { response) }\end{array}$ \\
\hline$\varepsilon_{i j k l m n}$ & A random error caused by sampling \\
\hline
\end{tabular}

If significant differences were detected, Bonferroni's multiple comparison procedure was used to compare all pairwise differences of the least-square means. For each significance test, $\alpha=0.05$. The percentage of cartilage in the skeleton was compared among the 6 agesize combinations as a 2-way factorial. Cartilage percentage was analyzed in the same way as the other parametric responses with the exception that the only treatments were age and size of the fish. All statistical analyses were conducted with the statistical software program SAS/STAT (SAS Institute 1996).

\section{RESULTS}

\section{Mortality}

The age (weeks post-hatch) of rainbow trout at first exposure, size (fork length) at first exposure and level of triactinomyxon dose did not significantly affect the cumulative mortality of fish at $20 \mathrm{wk}$ after exposure (age $\mathrm{p}=0.2236$; size $\mathrm{p}=0.6249$; dose $\mathrm{p}=0.0802$ ). Mortality rate was relatively low in all treatments (Fig. 2). Tendencies were evident for more mortality among positively-exposed fish and younger fish, but high variability in mortality among replicates, especially

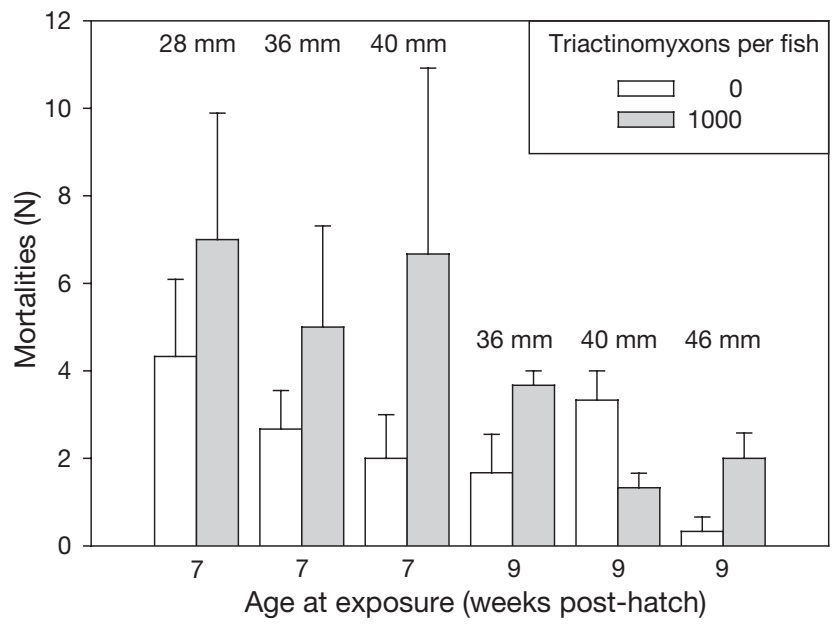

Fig. 2. Myxobolus cerebralis infecting Oncorhynchus mykiss. Mean (+SE) number of mortalities of rainbow trout at $20 \mathrm{wk}$ after exposure, exposed at different ages and sizes to either 0 or $1000 \mathrm{M}$. cerebralis triactinomyxons per fish. Numbers above bars represent mean fork lengths of fish at exposure

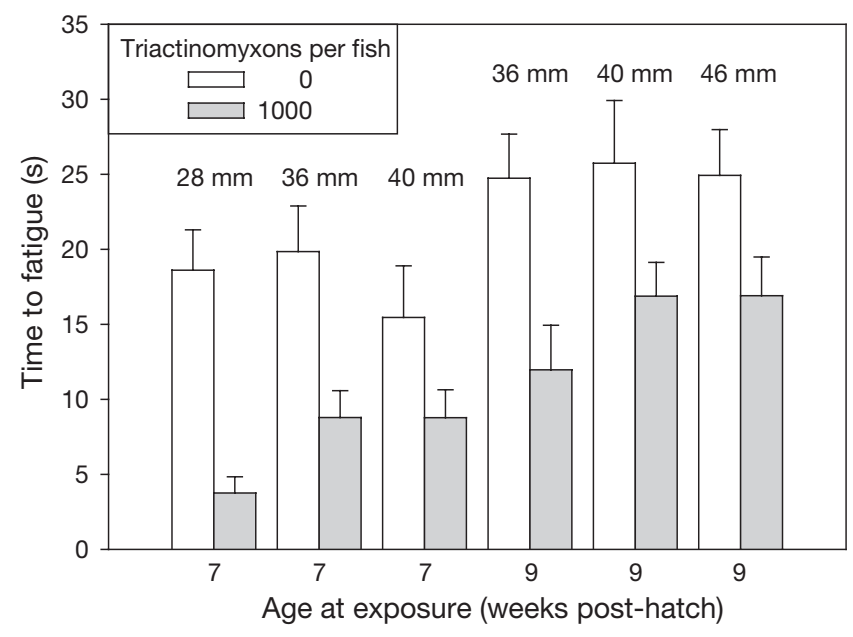

Fig. 3. Myxobolus cerebralis infecting Oncorhynchus mykiss. Mean (+SE) time to fatigue of rainbow trout at a water velocity of $35 \mathrm{~cm} \mathrm{~s}^{-1}$, exposed at different ages and sizes to either 0 or $1000 \mathrm{M}$. cerebralis triactinomyxons per fish, $20 \mathrm{wk}$ after exposure. Numbers above bars represent mean fork lengths of fish at exposure

among fish exposed at $7 \mathrm{wk}$ post-hatch, rendered such tendencies insignificant.

\section{Swimming performance}

Swimming performance was significantly affected by triactinomyxon dose ( $p=0.0002)$ (Fig. 3). Mean time to fatigue of sham-exposed fish exceeded that of positively-exposed fish in all age-size combinations. Size at exposure did not significantly affect swimming performance $(p=0.9338)$ (Fig. 3$)$. Age at exposure did ( $p=$ 
0.0318) (Fig. 3), but pairwise comparisons revealed that only the mean time to fatigue of the $28 \mathrm{~mm}$ fish exposed at 7 wk post-hatch was significantly different from those of the 40 and $46 \mathrm{~mm}$ fish exposed at $9 \mathrm{wk}$ post-hatch (Table 1). No significant difference existed between the $36 \mathrm{~mm}$ fish or the $40 \mathrm{~mm}$ fish exposed at 7 versus 9 wk post-hatch (Table 1).

\section{Clinical signs}

None of the control fish subjected to sham exposures exhibited clinical signs of whirling disease; triactinomyxon dose significantly affected the percentage of fish exhibiting clinical signs $(p<0.0001)$. Clinical signs were present at $20 \mathrm{wk}$ after exposure among all groups exposed to 1000 triactinomyxons per fish (Fig. 4).

Size at exposure significantly affected clinical sign prevalence ( $p=0.0132$ ) (Fig. 4), as did age at exposure $(p<0.0001)$, and a significant interaction effect was present between age and size $(p=0.0030)$. Size did not affect clinical sign prevalence among the fish exposed at $7 \mathrm{wk}$ post-hatch, but did among those exposed at $9 \mathrm{wk}$ post-hatch; the $9 \mathrm{wk}$ post-hatch fish exposed at 40 and $46 \mathrm{~mm}$ had significantly lower prevalences of clinical signs than did the fish exposed at $36 \mathrm{~mm}$ (Table 1). Age at exposure did not elicit a significant effect on clinical signs of fish exposed at $36 \mathrm{~mm}$, but did at $40 \mathrm{~mm}$ (Fig. 4, Table 1). Therefore, size at age affected prevalence of clinical signs only at the older exposure age $(9 \mathrm{wk}$ posthatch) and age at size affected clinical signs only at the larger size $(40 \mathrm{~mm})$.

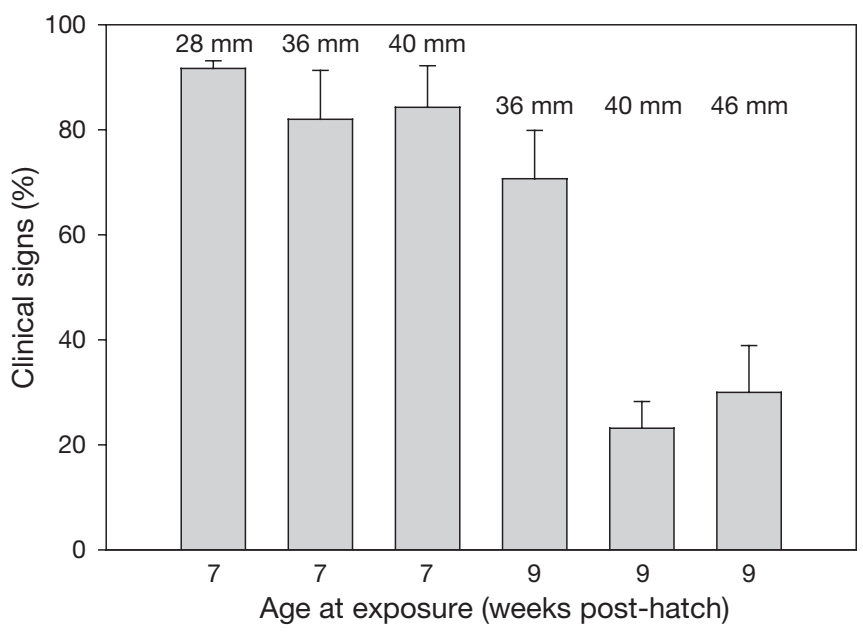

Fig. 4. Myxobolus cerebralis infecting Oncorhynchus mykiss. Mean (+SE) percentage of rainbow trout with clinical signs at $20 \mathrm{wk}$ after exposure, exposed at different ages and sizes to 1000 M. cerebralis triactinomyxons per fish. Numbers above bars represent mean fork lengths of fish at exposure

\section{Microscopic pathology}

No evidence of microscopic pathology attributable to Myxobolus cerebralis was present in any of the shamexposed controls. Significant differences existed among the frequency distributions of the microscopic pathology category of fish exposed at different sizes within each of the 2 age classes (both $\mathrm{p}<0.05$ ) (Fig. 5). However, the differences among the 3 size groups
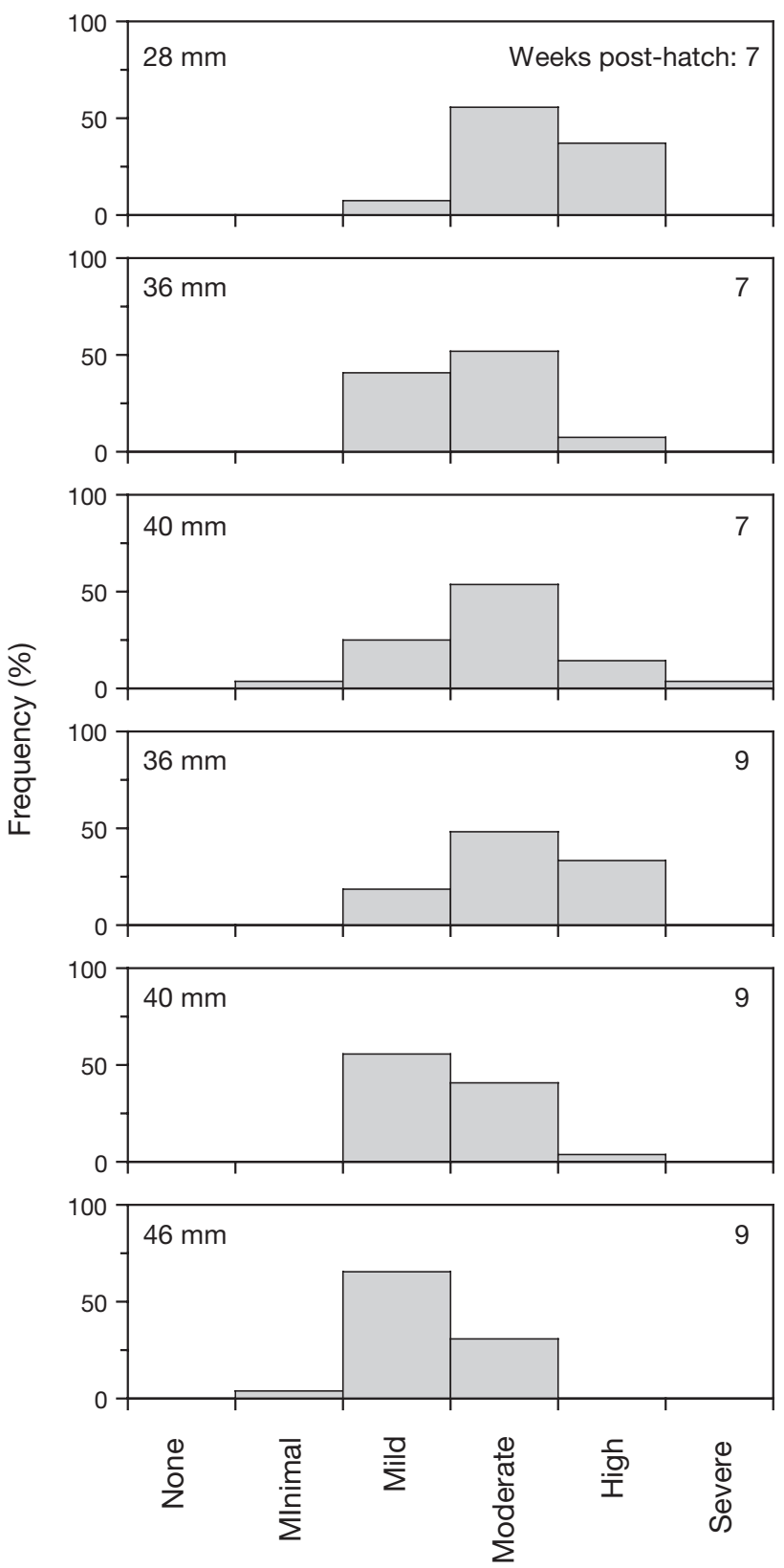

Fig. 5. Myxobolus cerebralis infecting Oncorhynchus mykiss. Frequency distributions of the microscopic pathology category for rainbow trout exposed to 1000 triactinomyxons per fish at different ages and sizes 
exposed at 7 wk post-hatch suggested only a slight shift to less severe pathology categories with increasing size; modal and median categories were 'moderate' for all 3 sizes (Fig. 5). Among fish exposed at $9 \mathrm{wk}$ posthatch, modal and median categories were 'moderate' for $36 \mathrm{~mm}$ fish at time of exposure, but shifted to 'mild' for both the 40 and $46 \mathrm{~mm}$ sizes (Fig. 5).

Frequency distributions of the microscopic pathology category were significantly different between fish exposed at the same size but at different ages (both $\mathrm{p}<$ 0.05) (Fig. 5). However, modal and median categories of both groups exposed at $36 \mathrm{~mm}$ were 'moderate' and more of the fish exposed at 9 wk post-hatch were categorized as 'high' than were fish exposed at $7 \mathrm{wk}$ post-hatch. Among fish exposed at $40 \mathrm{~mm}$, modal and median categories were 'moderate' for fish exposed at 7 wk post-hatch, but shifted to 'mild' for fish exposed at 9 wk post-hatch. As with clinical signs, size at age influenced the microscopic pathology category only at the older exposure age ( $9 \mathrm{wk}$ post-hatch) and age at size influenced the microscopic pathology category only at the larger size (40 $\mathrm{mm})$.

\section{Myxospore burdens}

Myxospores were found in none of the control fish subjected to sham exposures, but were present in all but 2 of the exposed fish. Myxospores were not detected in 1 fish exposed to 1000 triactinomyxons at $7 \mathrm{wk}$ post-hatch and $36 \mathrm{~mm}$ and 1 fish exposed at $9 \mathrm{wk}$ post-hatch and $46 \mathrm{~mm}$. Triactinomyxon dose significantly affected the presence of myxospores ( $p<$ 0.0001).

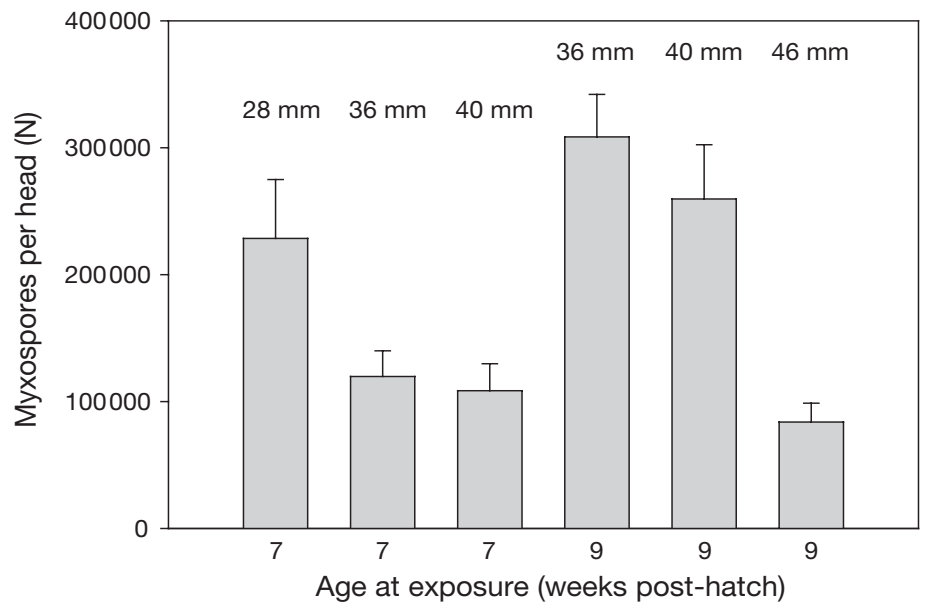

Fig. 6. Myxobolus cerebralis infecting Oncorhynchus mykiss. Mean (+SE) number of $M$. cerebralis myxospores per head in rainbow trout at $20 \mathrm{wk}$ after exposure, exposed at different ages and sizes to $1000 \mathrm{M}$. cerebralis triactinomyxons per fish. Numbers above bars represent mean fork lengths of fish at exposure
Size at exposure significantly affected myxospore burdens ( $p=0.0466$ ) (Fig. 6). Differences among sizes were not significant for the fish exposed at $7 \mathrm{wk}$ posthatch, but among those exposed at 9 wk post-hatch, the mean myxospore burden of fish exposed at $46 \mathrm{~mm}$ was significantly lower than in fish exposed at 36 and $40 \mathrm{~mm}$ (Table 1). Age at exposure also significantly affected myxospore burdens $(p=0.0117$ ) (Fig. 6), but the direction of the difference was opposite of that expected. Among fish exposed at both 36 and $40 \mathrm{~mm}$, myxospore burdens were greater among fish exposed at $9 \mathrm{wk}$ than at $7 \mathrm{wk}$ post-hatch (Fig. 6, Table 1). No significant interaction existed between effects of age and size on myxospore burdens $(p=0.7803)$

\section{Cartilage}

The percentage of cartilage present in the skeletons of fish was significantly affected by size ( $p<0.0001)$ (Fig. 7) but not by age ( $p=0.8287$ ) (Fig. 7); interaction between age and size was not significant $(p=0.0786)$. Only $28 \mathrm{~mm}$, 7wk old post-hatch rainbow trout (reared at $9.3^{\circ} \mathrm{C}, 456$ degree days) had a significantly higher mean percentage of cartilage $(81.03 \%)$ than all 5 other groups (41.56 to $49.29 \%$ ). No relation was evident between the percentage of cartilage and the patterns of whirling disease severity shown by any of the indicators of whirling disease severity. For all responses, the $28 \mathrm{~mm}$ group did not consistently exhibit more severe symptoms than all 5 other groups (Table 1, Figs. 2 to 6), which all possessed similar amounts of cartilage. Moreover, significantly different levels of disease severity were present among the 5 groups with

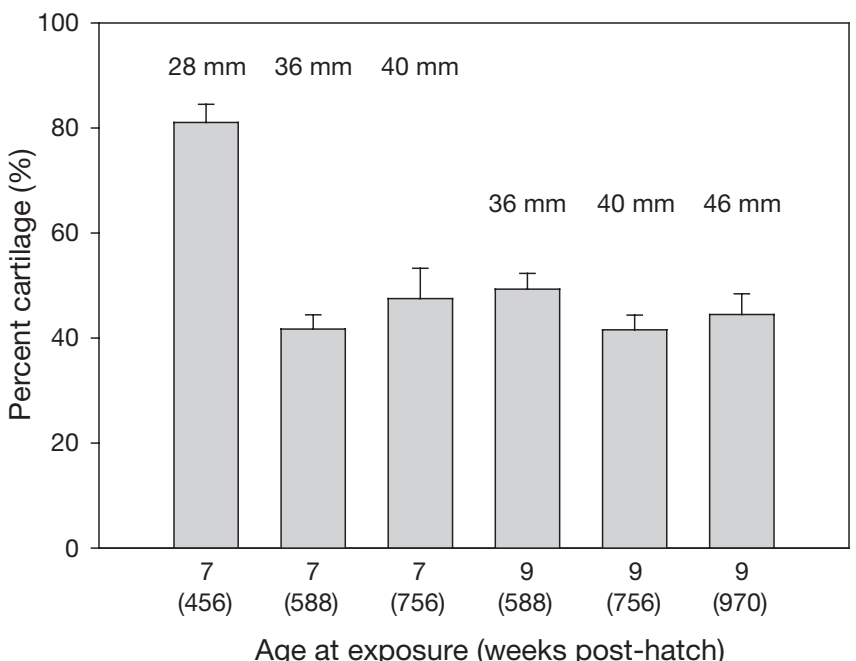

Fig. 7. Oncorhynchus mykiss. Mean (+SE) percentage of cartilage in skeletons at different ages and degree days (in parentheses) of development. Numbers above bars represent mean fork lengths of fish at exposure 
no significant difference in the percentage of cartilage. No change in the level of skeletal ossification was associated with the ages and sizes at which resistance was conferred.

\section{DISCUSSION}

Clinical signs, microscopic pathology and myxospore burdens provided clear evidence that size at age (and corresponding degree days of development) influenced whirling disease severity. Corresponding evidence was not apparent using cumulative mortality or swimming performance, the results of which were equivocal. The effect of size was evident only among exposures at 9 wk post-hatch; increased size was ineffectual at 7 wk post-hatch. Similarly, clinical signs, microscopic pathology and myxospore burdens indicated effects of age at size. Effects were evident only at $40 \mathrm{~mm}$ using clinical signs and microscopic pathology, and at both 36 and $40 \mathrm{~mm}$ using myxospore burdens, albeit opposite of the expected direction. Thus, increased protection was conferred only at an age of 9 wk post-hatch and sizes greater than or equal to $40 \mathrm{~mm}$. Neither increased size of younger fish $(7 \mathrm{wk}$ post-hatch), nor increased age of smaller fish (36 mm), consistently altered susceptibility to whirling disease. The mechanisms needed to provide protection against development of the disease were apparently unavailable in the younger and smaller fish; however, among older and larger fish, only a slight increase in age or size was sufficient to induce resistance. Therefore, both age and size affect development of resistance to whirling disease in rainbow trout. Our earlier conclusions that the development and severity of whirling disease pathology in rainbow trout were dependent on their age when first exposed to the parasite and that resistance to the development of the disease was conferred at about 9 wk post-hatch or older (Ryce et al. 2004) should be amended to include size as a regulating factor. Age alone does not confer resistance in the absence of sufficient size. Erwin strain rainbow trout must be both 9 wk post-hatch or older and at least $40 \mathrm{~mm}$ in fork length at time of exposure to exhibit enhanced resistance to whirling disease, compared to fish first exposed to the parasite at earlier stages of development. These specific thresholds are likely not universally applicable to all strains of rainbow trout and certainly not to other salmonids, but the interactive effects of age and size may be a general phenomenon.

It has long been hypothesized that the decreasing severity of whirling disease with increasing age or size of fish at first exposure occurs because of a corresponding increase in ossification of the skeleton (Halliday
1973, Schaperclaus 1991, El-Matbouli et al. 1992, Garden 1992). Trophozoites of Myxobolus cerebralis target and digest cartilage (El-Matbouli et al. 1992), thereby destroying the structural framework needed for healthy bone formation and causing permanent skeletal disfiguration. Abundant cartilage in the skeletons of young trout would therefore seem to render them especially vulnerable to such damage and we would expect whirling disease severity to decrease proportionately with the conversion of cartilage to bone; however, we found no such relation. The one treatment group ( $28 \mathrm{~mm}, 7$ wk post-hatch, 456 degree days) that had a significantly lower level of skeletal ossification did not differ systematically from the other groups in severity of disease. Other factors or processes related to age and size apparently dictate disease susceptibility.

Resistance to a pathogen can be caused by reduced penetration of the host, induction of antibody or interferon production, or inactivation of the pathogen by serum components, phagocytic cells, acute-phase proteins, or killer cells (Chevassus \& Dorson 1990). Rainbow trout develop humoral and cellular immune responses to the whirling disease pathogen, but only after significant cartilage damage has occurred (Hedrick et al. 1998). Specific anti-Myxobolus cerebralis antibodies are not present until 12 wk after exposure to the parasite (Ryce 2003). An induced immune response therefore cannot be responsible for enhanced resistance to disease at $9 \mathrm{wk}$ post-hatch. Non-specific immune mechanisms that develop ontogenetically may instead provide resistance against development of the disease. Development and maturation of the central nervous system may also be involved. Perineural granulomatous inflammation caused by destruction of adjacent cartilage coincident with rapid neural development in immature fish may elicit neuropathology and dysfunction of the central nervous system (Rose et al. 2000). Resistance to disease may therefore be related directly to the stage of development of the central nervous system.

We did not expect to find greater myxospore burdens in 36 and $40 \mathrm{~mm}$ fish exposed at $9 \mathrm{wk}$ post-hatch than in those exposed at the same sizes at 7 wk posthatch. In our earlier work, we showed that myxospore counts generally decreased with increasing age at exposure (Ryce et al. 2004). However, we also observed some age-specific departures from the general trend in that study, suggesting that myxospore burden may not correlate well with other indicators and its variability may be relatively high. In the absence of direct mortality, clinical signs and microscopic pathology are perhaps the most direct measures of disease severity. Myxospore burden, on the other hand, is only an indirect indicator of whirling disease 
severity as it is a direct measure only of the success of the parasite in proliferating within a fish, which may not necessarily also relate to disease severity in that fish. For example, both the 36 and $40 \mathrm{~mm}$ fish exposed at 7 wk post-hatch in the present study exhibited high incidences of clinical signs and 'moderate' microscopic pathology medians, but harbored low myxospore burdens (Figs. 4, 5 \& 6). Fish exposed at $40 \mathrm{~mm}$ and $9 \mathrm{wk}$ post-hatch had a low incidence of clinical signs and a 'mild' microscopic pathology median, but harbored high myxospore burdens (Figs. 4, 5 \& 6). The anomalous relations we found among myxospore burdens and ages and sizes of exposed fish may have resulted from this poor correspondence between myxospore burden and disease severity.

Acknowledgements. We thank the Whirling Disease Initiative of the National Partnership on Management of Wild and Native Coldwater Fisheries for funding this work. C. Fraser, Laboratory Manager of the Wild Trout Research Laboratory, D. Rider, T. Jentzsche, C. Singer, C. Kohler and A. Smith provided technical assistance. J. Borkowski provided statistical advice. C. Bond, B. L. Kerans, T. E. McMahon and C. Zabinski reviewed an earlier version of the manuscript.

\section{LITERATURE CITED}

Chevassus B, Dorson M (1990) Genetics of resistance to disease in fishes. Aquaculture 85:83-107

Daniel WW (1990) Applied nonparametric statistics, 2nd edn. PWS-Kent, Boston

El-Matbouli M, Fischer-Scherl T, Hoffmann RW (1992) Present knowledge on the life cycle, taxonomy, pathology, and therapy of some Myxosporea spp. important for freshwater fish. Annu Rev Fish Dis 3:367-402

Fritzsche RA, Johnson GD (1980) Early osteological development of white perch and striped bass with emphasis on identification of their larvae. Trans Am Fish Soc 109: $387-406$

Garden O (1992) The myxosporea of fish: a review. Br Vet J 148:223-239

Halliday MM (1973) Studies of Myxosoma cerebralis, a parasite of salmonids. I. The diagnosis of the infection. Nord Vetmed 25:345-348

Halliday MM (1976) The biology of Myxosoma cerebralis: the causative organism of whirling disease of salmonids. J Fish Biol 9:339-357

Hedrick RP, El-Matbouli M, Adkison MA, MacConnell E (1998) Whirling disease: reemergence among wild trout. Immunol Rev 166:365-376

Hedrick RP, McDowell TS, Gay M, Marty GD, Georgiadis MP, MacConnell E (1999a) Comparative susceptibility of rainbow trout Oncorhynchus mykiss and brown trout Salmo trutta to Myxobolus cerebralis, the cause of salmonid whirling disease. Dis Aquat Org 37:173-183

Hedrick RP, McDowell TS, Mukkatira K, Georgiadis MP, MacConnell E (1999b) Susceptibility of selected inland salmonids to experimentally induced infections with Myxobolus cerebralis, the causative agent of whirling disease. J Aquat Anim Health 11:330-339
Hoffman GL (1961) Whirling disease (Myxosporidia: Myxosoma) of trout. US Department of Interior, Fish and Wildlife Service, Fishery leaflet 508, Washington, DC

Hoffman GL (1976) Whirling disease of trout. US Department of Interior, Fish and Wildlife Service, Fish Disease Leaflet 47, Washington, DC

Littell RC, Milliken GA, Stroup WW, Wolfinger RD (1996) SAS system for mixed models. SAS Institute, Cary, NC

Lom J (1987) Myxosporea: a new look at long-known parasites of fish. Parasitol Today 3:327-332

Markiw ME (1991) Whirling disease: earliest susceptible age of rainbow trout to the triactinomyxid of Myxobolus cerebralis. Aquaculture 92:1-6

Markiw ME (1992) Experimentally induced whirling disease. I. Dose response of fry and adults of rainbow trout exposed to the triactinomyxon stage of Myxobolus cerebralis. J Aquat Anim Health 4:40-43

Montgomery DC (1997) Design and analysis of experiments, 4th edn. John Wiley \& Sons, New York

O'Grodnick J (1975) Whirling disease Myxosoma cerebralis spore concentration using the continuous plankton centrifuge. J Wildl Dis 11:54-57

O'Grodnick JJ (1979) Susceptibility of various salmonids to whirling disease (Myxosoma cerebralis). Trans Am Fish Soc 108:187-190

Rose JD, Marrs GS, Lewis C, Schisler G (2000) Whirling disease behavior and its relation to pathology of brain stem and spinal cord in rainbow trout. J Aquat Anim Health 12: $107-118$

Ryce EKN (2003) Factors affecting the resistance of juvenile rainbow trout to whirling disease. $\mathrm{PhD}$ dissertation, Montana State University, Bozeman, MT

Ryce EKN, Zale AV, MacConnell E (2004) Effects of fish age and parasite dose on the development of whirling disease in rainbow trout. Dis Aquat Org 59:225-233

SAS Institute (1996) SAS statistical software: release 6.12. SAS Institute, Cary, NC

Schaperclaus W (1991) Fish Diseases, Vol 2, translated from German. Akademie-Verlag, Berlin

Song J, Parenti LR (1995) Clearing and staining whole fish specimens for simultaneous demonstration of bone, cartilage, and nerves. Copeia 1995(1):114-118

Thomas AE, Burrows RE, Chenoweth HH (1964) A device for stamina measurement of fingerling salmonids. US Department of Interior, Fish and Wildlife Service, Research Report 67, Washington, DC

Thompson KG, Nehring RB, Bowden DC, Wygant T (1999) Field exposures of seven species or subspecies of salmonids to Myxobolus cerebralis in the Colorado River, Middle Park, Colorado. J Aquat Anim Health 11: 312-329

Webb GN, Byrd RA (1994) Simultaneous differential staining of cartilage and bone in rodent fetuses: an alcian blue and alizarin red $\mathrm{S}$ procedure without glacial acetic acid. Biotech Histochem 69:181-185

Webb PW, Brett JR (1973) Effects of sublethal concentrations of sodium pentachlorophenate on growth rate, food conversion efficiency, and swimming performance in underyearling sockeye salmon (Oncorhynchus nerka). J Fish Res Board Can 30:499-507

Wedemeyer GA, Barton BA, McLeay PB (1990) Stress and acclimation. In: Schreck CB, Moyle PB (eds) Methods for fish biology. American Fisheries Society, Bethesda, MD, p 451-498

Wolf K (1986) Salmonid whirling disease: status in the United States, 1985. J Wildl Dis 22:295-299

Submitted: January 2, 2004; Accepted: April 27, 2004

Proofs received from author(s): November 25, 2004 